\title{
ESP AS AN APPROACH OF ENGLISH LANGUAGE TEACHING IN ITS
}

Endang Susilowati

\begin{abstract}
According to National Curriculum Preparation Guideline 2004 - 2009, teaching English in ITS is classified into General Studies ( MKU ) and distributed into " Personality Development - Related subject “( MPK - Mata Kuliah Pengembangan Kepribadian ). However, English as subject has been redundantly placed within the ITS curriculum. While under the curriculum preparation guideline the subject falls into the category of Personality - Development related subjects, the course content involves a significant degree of skills that are required by the students during learning process at ITS. The teaching of English at ITS should therefore be designed to meet the demands for personality development, as well as knowledge and skills improvement. In the attempt of meeting these demands, the English teaching staff have agreed to adopt the ESP approach.

The popular principle of English for Specific Purposes ( ESP ) is "Tell me what you need English for and I will tell you the English that you need". This principle suggests that ESP is an approach to language teaching which is oriented to fulfil learners'needs. So teaching English at the tertiary level for non English Department such as in ITS is still mostly concentrated on the need for the capability of reading relevant text books. The teaching of English is focused on the reading skill specialized in relevant text books which will reinforce the mastery of basic vocabulary and grammar because mastering reading skill is determined mostly by those two elements. However, this shift to gives other study skills such as note taking, group discussion, presentation and academic writing.
\end{abstract}

Keywords : English Language Teaching Approach, National Curriculum Preparation Guideline, Personality Development - Related Subjects ( MPK Mata Kuliah Pengembangan Kepribadian )

In Indonesia the demand of English language teaching has been increasing both in private sectors and in formal institutions such as those in state and private universities. Advances in commerce and industry that require people to have adequate command of the language both spoken and written have generated the demands. In spite of increasing demand for English language teaching, the situation has not invoked sufficient research in ESP (English for Specific Purposes), especially the need of various groups of learners or people who need to have sufficient command in English. The need to address the ESP issue is further necessitated by the fact that the result of English language teaching at the 
secondary level has not been very encouraging despite six years' study of English At the tertiary levels complaints of university teachers and employers show that skills in English such as writing reports, reading scientific books, and taking part in academic discussion are not sufficiently mastered (Astika, 1999).

\section{English for Specific Purposes}

Hutchinson and Waters defined ESP as an approach of language teaching in which all decisions as to content and method are based on the learners' reasons for learning (Hutchinson and Waters, 1987). Strevens defined ESP as a particular case of the general category of special-purpose language teaching. The same principles apply no matter which language is being learned and taught. French for specific purposes, Russian for specific purposes, Italian for specific purposes and Chinese for specific purposes- all of these exist and are constructed on the same basis as English for specific purposes.

The vastly demand of English made ESP more common than the others, but the principles are the same. Furthermore, he stated that a definition of ESP needed to distinguish between four absolute and two variable characteristics. The four absolute characteristics are ESP consists of English language teaching, which is: design to meet specified needs of the learner, related to content (i.e. in its themes and topics) to particular disciplines, occupations, and activities, centred on the language appropriate to those activities in syntax, lexis, discourse, semantics, etc and analysis of this discourse, and in contrast with General English. While the two variable characteristics are ESP may be, but is not necessarily: restricted as to the language skills to be learned (e.g. reading only), not taught according to any pre-ordained methodology (Strevens, 1988).

Dudley-Evans and St John modified this definition by deleting the last absolute characteristic and adding more characteristics on the variable one. The revised definition they postulated is as follows: Absolute characteristics: ESP is defined to meet specific needs of the learner, ESP makes use of underlying methodology and activities of the discipline it serves, ESP is centred on the language (grammar, lexis, register) skills, discourse and genres appropriate to 
these activities; Variable characteristics: ESP may be related to or designed for specific discipline, ESP may use, in specific teaching situations, a different methodology from that of general English, ESP is likely to be designed for adult learners, either at a tertiary level institution or in a professional work situation. It could, however, be for learners at a secondary school level, ESP is generally designed for intermediate or advanced students, most ESP courses assume some basic knowledge of the language system, but it can be used with beginners (Dudley-Evans and St John, 1998).

A broader definition of ESP comes from Hutchinson and Waters. They defined ESP as an approach of language teaching in which all decisions as to content and method are based on the learners' reasons for learning (Hutchinson and Waters, 1987). Robinson viewed ESP as an enterprise involving education, training and practice and drawing upon three major realms of knowledge; language, pedagogy, and students' / participants' specialist area of interest (Robinson, 1991).

Richards and Rodgers saw ESP as a movement that seeks to serve the language needs of learners who need English in order to carry out specific roles (e.g. student, engineer, nurse) and who need to acquire content and real-world skills through the medium of it rather than master the language for its own sake (Richards and Rodgers, 2001).

The word "specific" in ESP has different interpretation along with the development of this area. In 1960's it meant a list of technical vocabulary of a given field or profession (Hutchinson and Waters, 1987), (Dudley-Evans and St John, 1998), (Smoak: 2003). In 1980's up to now it referred to the learners' needs and interests (Hutchinson and Waters, 1987), (Strevens, 1988), (John, 1995), (Dudley-Evans and St John, 1998). All of the above experts agrees that to identify the learners' need and interest, a need analysis must be taken as what is specific and appropriate in one particular group of learners may well not be elsewhere.

The program of English for Specific Purposes (ESP) has been developed at university level and in occupational setting (Suyanto, 2004). This is especially 
intended to meet particular instructional objectives such as to be able to read English text in the students' field of study, to be able to write laboratory activities reports, and to make presentation.

A number of factors contribute to the development and popularity of ESP. The advancement of technology and commerce demand practitioners to master specific language skills (Block and Cameron, 2002). A shift of paradigm in educational psychology to learners and their attitude to learning gives ESP extra fuel to speed up (Hutchinson and Waters, 1987).

Technological change is connected to economic change, since the operation of global markets depends on the rapid information flows made possible by new information and communication technologies. But the effect of technological changes are not confined to the economic sphere; they are also seen in the development of new cultural forms and the popularity of new leisure activities such as visiting on-line "chat rooms". Education too, is increasingly affected by the advent of new technologies and media. These are having a significant impact on second language teaching and in the process raising questions about the specific language skills required to engage in and the potential of technology to radically change the experience of learning languages. It is obviously noted that the relationship between technology and language especially English create a new demand for any parties engaged in the development of a new civilization and in turn the need of specific language teaching cannot be neglected (Block and Cameron, 2002).

Astika also viewed the development of technology and commerce as the central factor to the rise of ESP. He stated that the continuous advancement of commerce and technology has created the needs for students and professionals to master the language of commerce and technology not only for academic purposes but also for occupational purposes. The role of English in commerce and technology has been widely recognized and English courses, which cater for this, have been and will continue to play a significant role in the development of commerce and technology (Astika, 1999). 
The rise of ESP is also caused by new development in educational psychology emphasizing on the learners and their attitude to learning. Learners were seen to have different needs and interests, which would have an important influence on their motivation to learn and therefore on their effectiveness of their learning (Hutchinson and Waters, 1987).

The effect is to create a whole new mass of people wanting to learn English not for the pleasure or prestige of knowing the language, but because English was the key to the international currencies of technology and commerce. A critical question was aroused why it was necessary to learn English or any other languages. As English become the accepted international language of technology and commerce, it created a new generation of learners who knew specifically why they were learning a language, such as business people who wanted to sell their products, mechanics who had to read instruction manuals, doctors who needed to keep up with developments in their field and a whole range of students whose course of study included textbooks and journals only available in English. All these and many others needed English and, most importantly, they knew why they needed it (Hutchinson and Waters, 1987).

ESP approach requires a well-designed and research curriculum and pedagogy for a specified group of students. ESP should not be taught in a vacuum, but should prepare students, in the most efficient way possible, for the content and tasks to which they will be exposed. English instructors should increase their efforts to provide for the students what is most appropriate for them (Johns, 1995).

Teaching English at the tertiary level for non English Department is still mostly concentrated on the need for the capability of reading relevant text books. The teaching of English is focused on the reading skill specialized in relevant text books which will reinforce the mastery of basic vocabulary and grammar because mastering reading skill is determined mostly by those two elements. However, this shift to gives other study skills such as note taking, group discussion, presentation and academic writing. 


\section{English as One of General Studies (MKU English) in ITS}

According to National curriculum preparation guideline 2004 - 2009, teaching English in ITS is classified into General Studies (MKU) and distributed into "Personality development - related subjects (MPK - Mata Kuliah Pengembangan Kepribadian). However, English as subject has been redundantly placed within the ITS curriculum. While under the curriculum preparation guideline the subject falls into the category of Personality - Development related subjects, the course content involves a significant degree of skills that are required by the students during learning process at ITS. The teaching of English at ITS should therefore be designed to meet the demands for personality development, as well as knowledge and skills improvement. In the attempt of meeting these demands, the English teaching staff have agreed to adopt the ESP approach.

In the 80s and 90s English Language Teaching in ITS was managed by each department. The focus of the instruction was reading comprehension although the students also participated in lab work 5 times a semester to have listening practice. The materials designed by English teaching team cover the general topic of science and technology in the first half of the semester and the specific interest of each department in the other half. In the late of 90s, Civil Engineering Department D3 Program and Statistics Department S1 Program employed English 2. Another 2 credits (SKS) were added, consequently, the students in those departments had 4 credits of English instruction. The additional instruction covered the materials deriving from their field of study with reading as the focused skill. Since 2000 the teaching of English has been academically administered by TPB (Tahun Persiapan Bersama) The 2 credits English instruction in the first year were done incross-departmental classes in which the stuidents come from all ITS S1 departments. Meanwhile, the D3 programs managed English instruction by themselves. The 2 credits of English held by Civil Engineering and Statistics Department are still there until the new ITS curriculum 2004-2009. They no longer exist. ITS employs Advanced English (Bahasa Inggris Lanjut) in form of TOEFL score issued by ITS Language Centre (UPT Pusat Bahasa ITS). The score, then is converted into alphabetical scoring (A, 
$\mathrm{AB}, \mathrm{B}, \mathrm{BC}, \mathrm{C}, \mathrm{D}$, and E). Language Laboratory is assigned to carry out TOEFL Preparation tutorials to bring the students to achieve the required passing score 450 for S!, 475 for S2, and 500 for S3. In short, at the moment All ITS Departments except Polytechnic have 4 credits (sks), 2 credits MKU English and the other 2 TOEFL conversions.

The constrains of conducting the 2 sks MKU English derive from: Student: various English proficiency level in one class, background knowledge, expectation, need, motivation; System: big classes (40 to 50), short term (1 semester), facilities.

The following is English language teaching and learning (MKU English) according to ITS Curriculum (2004 - 2009) course title is English, code is UG. 1201, credit/hour are 2 credits / 100 minutes per week, position are 1st or 2nd Semester, status is compulsory.

\section{Course Description}

The course provides skills and strategies required by the students of science and technology to anticipate English tasks required during their course of study, particularly the reading task. It also gives study skills involving English such as texts summarizing texts, presentation, and listening to academic talks.

\section{Course objectives}

At the end of the course, the students will be able to : read, comprehend, and summarize science and technology written texts in English, give short academic presentation in English, listen and comprehend academic talks in English.

\section{Instructional strategies}

The course employs both classroom activities and laboratory works in the form of: individualized instruction, pair - work, group work, class discussion.

\section{Instructional materials}

The course utilizes the text book designed by English teaching team which is also served as work book. The materials are also generated by the students to cover their need of authentic materials in their field of study.

\section{Assessment}


The students grade of the course derives from: written test (mid and final test), listening test (language lab), portfolio (through out the course).

Percentage of evaluation : class assignments:10\%, lab. work: $20 \%$, mid test: 30 $\%$, final test: $40 \%$.

References: Mackay, $\mathrm{M}$ et al, English for Specific Purposes, Longman London; Bate, Martin et al. English for General Science and Technlogy, Longman; Dudley-Evans, Tony and St John, Maggie Jo, 1998. Developments in English for Specific Purposes.

The constrains of conducting the 2 sks Advanced English (Bahasa Inggris Lanjut (TOEFL Conversion) derive from:

- The justification of conducting; The students will get the score only by taking TOEFL ITS Version without any instructions except for those having scores lower than passing score 450 for S1 and D3, 475 for S2 and 500 for $\mathrm{S} 3$.

- The students' English learning orientation; the students tend to study English just to get the passing score.

\section{Conclusion}

Currently ITS employs 4 credits (sks) of English language teaching, 2 sks MKU English conducted in the $1^{\text {st }}$ or $2^{\text {nd }}$ semester managed by TPB for S1 and D3 study program for D3, and another 2 credits (sks) as a result of ITS TOEFL Version convertion. MKU English has large classes 40 -60 students. The students derived from various ITS Department. The class is formed based on the variety of Departemnt represented not on the students' English proficiency. This, in turn, create a very diverse class in terms of students' proficiency leading to the difficulty in designng instructional materials and applying instructional strategies. The latter seems rather awkward as there is no instruction delivered except for the students who have not achieved the required score. Once a student has taken the TOEFL test and got the required score., s/he does not necessarily take it again otherwise s/he wanto to have higher grade. 
I strongly proposed that the freshmens' ITS TOEFL Version score is used as the basis for classifying the MKU English class, so that the students will get more effective instruction in accordance with their English proficiency and the English teaching team is easier to design English instruction to fulfill their needs. The 2 sks Advanced Engliah (Bahasa Inggris Lanjut) grade should not derive from ITS TOEFL Version conversion. There must be a clear instructional activities which is benefit most to the students. The required TOEFL score can still be implemented as the basis for graduation

\section{Reference List}

Astika, Gusti, 1999, The Role of Needs Analysis in English for Specific Purposes, in TEFLIN Journal Vol X No: 1 August 1999.

Block, David and Cameron, Deborah, 2002, Globalization and Language Teaching, Routledge, The Great Britain.

Brown, Douglas H., 2001, Teaching by Principles: An interactive approach to language pedagogy, Addison Wesley Longman.

Bynom, Anthony, 2000, Team Teaching Plus or Minus ESP, in English Teaching Forum Vol 38 No: 1 January 2000.

Douglas, Dan, 2000, Assessing Language for Specific Purposes, Cambridge University Press., Cambridge.

Dubin, F and Olshtain, E., 1992, Course Design, Developing Programs and Materials for Language Learning, Cambridge University Press., Cambridge.

Dudley-Evans, Tony and St John, Maggie Jo.,1998, Developments in English for Specific Purposes, Cambridge University Press., Cambridge.

Gatehouse, Kristen, 2001, Key Issues in English for Specific Purposes Curriculum Development, in ITESL Journal Vol VII No; 10 October 2001.

Harmer, Jeremy, 1998, How to teach English, Addison Wesley Longman.

Harmer, Jeremy, 2001, The Practice of English Language Teaching, Addison Wesley Longman.

Hutchinson, Tom and Waters, Alan, 1987, English for Specific Purposes: A Learning-centred approach, Cambridge University Press., Cambridge.

Johns, A., 1995, The Current Situation of ESP, in Master Peter, Responses to ESP, San Jose State University Press.

Nunan, D., 1999, Second Language Teaching and Learning, Heinle and Heinle Publisher, USA.

Nunan, D., 2000, Language Teaching Methodology: A Textbook for Teachers, Prentice-Hall International, Longman Publisher, Malaysia.

Richards, J.C., 2001, Curriculum Development in Language Teaching, Cambridge Language Education, Cambridge. 
Richards, Jack C and Rodgers, Theodore S., 2001, Approaches and Methods in Language Teaching, Cambridge University Press., Cambridge.

Robinson, Pauline C., 1991, ESP Today: A Practitioner's Guide, Prentice Hall, New York.

Smoak, Rebecca, 2003, What is English for Specific Purposes, English Teaching Forum, Vol 41 No: 2 April 2003.

Strevens, Peter, 1988, ESP after twenty years, a re-appraisal in ESP State of the Art, SEAMEO Regional Language Centre.

Suyanto, Kasihani, K.E., 2004, ESP Course Design, Basic Feature and Design, Paper Presentation at Workshop on Curriculum Development at Tahun Pertama Bersama (TPB) ITS, Unpublished.

Trimble, Louise, 1985, English for Science and Technology: A discourse approach, Cambridge University Press, Cambridge. 